\title{
Menggunakan Studi Kasus sebagai Metode Ilmiah dalam Psikologi
}

\author{
Unika Prihatsanti ${ }^{1}$, Suryanto ${ }^{2}$, E Wiwin Hendriani ${ }^{3}$ \\ ${ }^{1}$ Fakultas Psikologi Universitas Diponegoro \\ 2,3Fakultas Psikologi Universitas Airlangga
}

\begin{abstract}
As a research method, case studies are often used in qualitative research, but there is no agreement on research procedures. Case studies have been widely used in psychology, which is not only used in the context of research but it has different meanings. The purpose of this article is to provide a description of the case study as a research method, by providing an overview of the procedures for conducting research which includes when case studies can be used, research design, data collection, data validity, and data analysis. This article seeks to help emerging researchers in the field of psychology with several views from Robert Yin and Robert Stake. This article helps researchers to familiarize themselves with the procedures of qualitative research using case studies. A case study approach that is applied correctly can be a valuable method for conducting research, especially in the field of psychology as a means of developing theory, evaluating programs, developing interventions..
\end{abstract}

Keywords: case study; psychology; qualitative

\section{Pengantar}

Mempelajari kasus, sudah sering digunakan dalam ranah bidang kesehatan, psikologi, organisasi, dan bidang lain untuk menunjukkan hal-hal penting dari kasus yang dipelajari. Studi kasus digunakan untuk memberikan pemahaman akan sesuatu yang menarik perhatian, proses sosial yang terjadi, peristiwa konkret, atau pengalaman orang yang menjadi latar dari sebuah kasus. Sebuah studi kasus diharapkan dapat menangkap kompleksitas satu kasus dan metodologi ini semakin berkembang dalam ilmu-ilmu sosial, termasuk dalam bidang yang berorientasi pada

\footnotetext{
1 Korespondensi artikel ini dapat dilakukan melalui: unik0206@gmail.com; suryanto@psikologi.unair.ac. id; wiwin.hendriani@unair.ac.id
}

praktik seperti studi lingkungan, pendidikan, maupun bisnis (Johanson, 2003).

Studi kasus (case study) berciri kualitatif namun sebagian lagi tidak. Misalnya studi kasus penyakit pada kedokteran, rekam medis lebih bercorak kuantitatif daripada kualitatif. Sebagai pendekatan, kunci penelitian studi kasus memungkinkan untuk menyelidiki suatu peristiwa, situasi, atau kondisi sosial tertentu dan untuk memberikan wawasan dalam proses yang menjelaskan bagaimana peristiwa atau situasi tertentu terjadi (Hodgetts \& Stolte, 2012). Lebih lanjut Hodgetts \& Stolte (2003) menjelaskan bahwa studi kasus individu, kelompok, komunitas membantu untuk menunjukkan hal-hal penting yang menjadi perhatian, proses sosial masyarakat dalam peristiwa yang konkret, pengalaman pemangku kepentingan. Kasus dapat 
mengilustrasikan bagaimana masalah dapat diatasi melalui penelitian.

Penelitian studi kasus sering digambarkan sebagai metodologi yang fleksibel, menantang dan paling umum digunakan dalam penelitian ilmu sosial. Namun demikian dukungan dan perhatian terhadap studi kasus paling sedikit karena tidak adanya protokol yang terdefinisi dengan baik (Cope, 2015), tidak ada standardisasi atau formula bagaimana melakukan penelitian studi kasus (Yin, 2002). Adanya kritik terhadap studi kasus didasarkan bahwa penelitian ini tidak dapat memberikan wawasan kausalitas dan generalisasi. Namun Krampen \& Krampen (2016) dalam artikelnya menjelaskan adanya peningkatan besar studi kasus dalam publikasi ilmiah berdasarkan temuan penelitian Glanxel \& Schubert. Sejumlah artikel dengan istilah "studi kasus" atau "laporan kasus" lebih banyak diterbitkan dalam ilmu kedokteran, biomedis, biologi dan diikuti ilmu sosial dan humaniora. Meskipun tidak secara spesifik menyebutkan psikologi, laporan dimasukkan dalam bidang illmu kedokteran, dan atau sosial. Pendekatan studi kasus banyak digunakan pada kasus klinis, dengan pendekatan interpretatif atau naratif kualitatif untuk mendukung kasus tunggal yang lebih kuantitatif dan sistematis (Krampen \& Krampen, 2016). Studi kasus memiliki fokus pada satu unit tertentu, yang dapat berupa individu, kelompok, organisasi, masyarakat. Artikel ini akan mendeskripsikan dan mendiskusikan penelitian studi kasus dan mengeksplorasi penggunaan metodologi ini dalam penelitian psikologi. Pendekatan ini bermanfaat untuk penelitian dalam mengembangkan teori, mengevaluasi program, dan mengembangkan intervensi karena fleksibilitas dan ketelitiannya (Baxter \& Jack, 2008).

\section{Pembahasan}

\section{Definisi Studi Kasus}

Penting untuk dipahami bahwa mendefinisikan studi kasus, tidak ada definisi tunggal termasuk dalam ilmu sosial terdapat definisi yang luas dan terbagi dalam empat kategori (Hentz, 2017). Teaching case tidak perlu menggambarkan individu, peristiwa atau proses tertentu secara akurat, karena tujuan utamanya untuk meningkatkan pembelajaran. Teaching case dapat berupa ilustrasi dan meskipun berasal dari pengamatan studi kasus tidak selalu sesuai dengan metodologi penelitian tertentu. Untuk tujuan pendidikan Yin menyatakan "A case study need not contain a complete or accurate rendition of actual events, rather, its purpose is to establish a framework for discussion and debate among students". (Yin, 2002).

Kriteria untuk mengembangkan kasus berasal dari single case, dan jauh berbeda dari studi kasus untuk tujuan penelitian. Misalnya studi kasus gangguan psikologi klinis yang didasarkan pada penelitian tertentu. Studi kasus ini dikembangkan menggunakan kombinasi kriteria diagnostik dan observasi klinis. Case history digunakan untuk peyimpanan catatan, tujuan utamanya bukan penelitian namun kasus-kasus ini bisa jadi berguna sebagai data dalam penelitian. Case work digunakan untuk menggambarkan manajemen perawatan kesehatan untuk pasien atau populasi. Case research/case study research dimaksudkan dengan tujuan menyelidiki kegiatan atau proses kompleks yang tidak mudah dipisahkan dari konteks sosial di mana hal itu terjadi. Kategori ini mempertahankan penggunaan metodologi dalam penelitiannya untuk menyajikan temuan yang akurat dan dapat diandalkan untuk mewakili data. 
Merriam \& Tisdell (2015) mendefinisikan studi kasus sebagai diskripsi dan analisis mendalam dari bounded system. Yin (2002) mendefinisikan studi kasus sebagai proses penelitian. "A case study is an empirical inquiry that ivestigates a contemporary phenomenon (the 'case') within its real-life context, especially when the boundaries between phenomenon and context may not clearly evident" (p.16). Sebuah studi kasus penelitian bertujuan untuk menguji pertanyaan dan masalah penelitian, yang tidak dapat dipisahkan antara fenomena dan konteks di mana fenomena tersebut terjadi.

\section{Kapan Studi Kasus Digunakan}

Pendekatan studi kasus, menurut Yin (2002) digunakan dengan mempertimbangkan (a) fokus penelitian adalah untuk menjawab pertanyaan "bagaimana" dan "mengapa"; (b) peneliti tidak dapat memanipulasi perilaku mereka yang terlibat dalam penelitian; (c) peneliti ingin menutupi kondisi kontekstual karena yakin hal itu relevan dengan yang diteliti; (d) batas tidak jelas antara fenomena dan konteks. Misalnya studi Yuliawan \& Himam (2007) tentang fenomena grasshopper, studi kasus profesional yang berpindah-pindah pekerjaan yang berusaha menentukan alasan para profesional ini berpindah pekerjaan. Studi kasus dipilih, karena kasusnya adalah para profesional yang berpindah kerja namun kasus tersebut tidak dapat dipertimbangkan tanpa konteks, yaitu di mana para profesional ini bekerja. Tidaklah mungkin peneliti mendapatkan gambaran benar tentang alasan profesional ini berpindah kerja tanpa mempelajari atau mempertimbangkan konteks di mana hal itu terjadi.

Peneliti studi kasus berfokus pada kasus tertentu secara mendalam sehingga dapat mengidentifikasi hubungan sosial, proses dan kategori yang secara bersamaan dapat dikenali, khas, dan unik. Sehingga diperlukan detail yang cukup untuk memberikan gambaran tentang sebuah kasus. Studi kasus biasanya spesifik, namun bukan berarti tidak dapat diterapkan pada proses sosial yang lebih luas. Penelitian studi kasus terdiri dari penyelidikan yang terperinci, seringkali data dikumpulkan pada periode waktu, fenomena dan konteks tertentu yang tujuannya untuk memberikan analisis tentang konsteks dan proses yang berkaitan dengan isu teoritis yang sedang dipelajari. Fenomena ini tidak dapat dipisahkan dari konteksnya, tetapi menjadi menarik ketika tujuannya memahami perilaku yang dipengaruhi oleh kontens tertentu (Hartley, 2004).

Ruang lingkup studi kasus yang digunakan dalam penelitian ketika studi kasus menyelidiki fenomena konteks kehidupan terutama ketika batasan antara fenomena dan konteks tidak dapat dipisahkan dengan jelas. Kedua, penyelidikan studi kasus berhubungan dengan situasi yang khas di mana banyak variabel yang menarik, bergantung pada banyaknya sumber bukti atau sumber data dengan data yang membutuhkan triangulasi dan pengecekan dengan hasil lainnya. Preposisi teoritis sebelumnya memberikan manfaat untuk memandu pengumpulan data dan analisis (Yin, 2002).

Hartley (2004) menjelaskan studi kasus dapat digunakan pada beberapa konteks. Pertama, pada konteks yang lebih luas, misalnya organisasi. Contohnya ketika menjelaskan job insecurity pada kasus kemunduran organisasi, peneliti dapat mengeksplorasi tentang job insecurity, bagaimana karyawan mengalami secara berbeda terkait hal tersebut, bagaimana tindakan yang dilakukan organisasi untuk memperbaiki kondisi tersebut. Sehingga studi kasus dapat berguna untuk mengeksplorasi proses atau perilaku yang muncul. "Case studies have an important function in 
generating hypotheses and building theory" (Hartley, 2004); kedua, studi kasus digunakan ketika memiliki tujuan untuk mengeksplorasi kasus yang 'aneh' atau ekstrim, misalnya perubahan organisasi yang ekstrim; ketiga, studi kasus berguna menangkap sifat yang muncul dan berubah dalam organisasi, yang tidak dapat ditangkap melalui survei karena proses atau aliran aktivitasnya yang demikian cepat, misalnya turnover karyawan yang tinggi; keempat, studi kasus merupakan teknik untuk mengeksplorasi perilaku organisasi informal, tidak biasa, rahasia bahkan terlarang; kelima, studi kasus digunakan untuk memahami praktik sehari-hari, di mana orang-orang yang terlibat tidak dapat dieksplorasi dalam kontak atau waktu yang singkat.

\section{Jenis Studi Kasus}

Peneliti perlu mempertimbangkan jenis studi kasus apa yang akan dilakukan, hal ini bergantung pada tujuan studi secara keseluruhan. Stake (1995) membagi studi kasus menjadi studi kasus intrinsik dan instrumental. Studi kasus instrinsik dilakukan karena peneliti menginginkan pemahaman lebih baik pada kasus khusus yang diteliti. Hal ini tidak dilakukan karena kasus tersebut mewakili permasalahan tertentu, tetapi dengan semua kekhususan dan keserupaan dalam kasus membuat kasus itu menjadi menarik. Tujuannya bukan untuk memahami fenomena umum melainkan lebih pada minat intrinsik pada fenomena tertentu, sehingga meskipun peneliti dapat membangun teori dari studi ini, hal itu bukan menjadi tujuan utama. Studi kasus instrumental digunakan ketika kasus diteliti terutama untuk memberikan wawasan tentang masalah atau untuk koreksi atas penelitian sebelumnya. Kasus bukan merupakan hal yang utama namun memiliki peran yang mendukung, memfasi- litasi pemahaman peneliti tentang sesuatu yang lain. Kasus dilihat secara mendalam, konteksnya diteliti, kegiatannya dirinci karena membantu peneliti menemukan tujuan penelitian. Sedangkan Yin (2002) membagi studi kasus menjadi, studi kasus eksplanatori, eksploratori, diskriptif. Studi kasus eksploratori, lapangan dan pengumpulan data dapat dilakukan sebelum adanya pertanyaan penelitian dan hipotesis. Jenis penelitian ini dianggap sebagai studi pendahuluan dalam beberapa penelitian sosial. Namun demikian, kerangka kerja penelitian tetap harus dibuat sebelumnya. Studi pendahuluan berguna untuk menentukan protokol/urutan akhir yang digunakan. Pertanyaan survei dapat ditambahkan berdasarkan studi pendahuluan. Studi kasus explanatori cocok digunakan dalam studi kasus kausal. Pada kasus yang kompleks dan multivariat, analisis dilakukan dengan teknik pencocokan pola. Studi kasus deskriptif merupakan bentuk diskripsi atas suatu kasus dan mengharuskan peneliti mulai dengan teori diskriptif

\section{Desain Studi Kasus}

Yin (2002) mendefinisikan desain sebagai "the logical sequence that connects the empirical data to a study's initial research questions and, ultimately, to its conclusions," dan menyarankan empat tipe desain penelitian yang dapat digunakan. Single holistic design, single embedded design, multiple holistic design dan multiple embedded design". Holistic design membutuhkan satu unit analisis, sementara embedded design membutuhkan unit analisis ganda. Pada perspektif ini desain studi kasus terdiri dari lima komponen, yaitu pertanyaan penelitian, preposisi jika, unit analisis, logika yang menghubungkan data dengan analisis, kriteria untuk menafsirkan temuan. Komponen keempat dan kelima menjadi perhatian karena digunakan untuk merencanakan analisis data. 
Berkaitan dengan komponen-komponen tersebut, Yin (2002) menyarankan bahwa peneliti perlu meninjau literatur yang relevan dan memasukkan proposisi teoritis mengenai kasus yang diteliti sebelum melakukan pengumpulan data. Hal inilah yang membedakan studi kasus dengan metode yang lain seperti grounded dan etnografi. Peneliti perlu meyakinkan bahwa desain yang dipilih merupakan desain yang ketat dan kuat dengan melakukan pengecekan secara terperinci. Jika terjadi perubahan desain pada saat pengambilan data, terutama ketika terjadi perubahan besar pada desain, peneliti seharusnya kembali ke langkah pertama konseptualisasi dan memulai kembali merancang penelitian. Yin memberikan struktur desain yang ketat pada metode studi kasus, sebaliknya Stake (1995) menyarankan desain yang fleksibel di mana peneliti dapat membuat perubahan meskipun terjadi pada proses penelitian. Stake hanya mengusulkan pada desain awal penelitian berkaitan dengan fenomena atau isu yang akan mengarahkan pada desain pertanyaan penelitian, yaitu "for intrinsic case study, case is dominant; the case is of highest importance. For instrumental case study, issue is dominant; we start and end with issues dominant" (Stake, 1995).

Merriam (2009) menjelaskan proses rancangan penelitian kualitatif dengan lebih rinci, termasuk di dalamnya adalah melakukan tinjauan literatur, membangun kerangka teoritis, mengidentifikasi masalah penelitian, menyusun dan mempertajam pertanyaan penelitian dan memilih sampel (purposive sampling). Pendekatan Merriam merupakan kombinasi pendekatan Yin dan Stake, dengan merekomendasikan desain yang fleksibel sampai pada batas tertentu. Sampling purposive terjadi sebelum data dikumpulkan, sedangkan sampling teoritis dilakukan bersamaan dengan pengumpulan data.

Sebagai bentuk penelitian, studi kasus ditentukan oleh minat pada kasus individual, apa yang dapat dipelajari dari sebuah kasus tunggal (Stake, 1995). Studi kasus dapat berupa single atau multiple case, di mana multiple case dilakukan dengan mereplikasi kasus. Penggunaan studi kasus tunggal dapat dilakukan ketika kasus mewakili (1) kasus kritis untuk menguji teori, (2) kasus yang tidak biasa atau unik, (3) kasus umum yang dapat menambah pemahaman pada peristiwa tertentu, (4) kasus yang sebelumnya tidak dapat diakses, (5) kasus longitudinal (Yin, 2002). Misalnya peneliti ingin mempertimbangkan topik tentang resiliensi karyawan yang terkena PHK, maka peneliti dapat menentukan hal ini menjadi satu kasus dengan satu karyawan atau satu kelompok karyawan yang diPHK. Namun demikian peneliti perlu mempertimbangkan juga konteksnya apakah para karyawan ini berada dalam satu lingkungan yang khusus/ekstrim. Jika demikian bisa jadi desain kasus tunggal bisa dipilih. Penelitian Yuliawan \& Himam (2007) dan Hendriani (2016) merupakan contoh penelitian menggunakan studi kasus tunggal.

Multiple case dipilih ketika peneliti tertarik untuk memeriksa kondisi atau temuan serupa yang dapat direplikasi. Ketika memilih beberapa kasus, tidak ada rumus tertentu yang menyebutkan berapa banyak kasus yang diperlukan. Secara umum dengan lebih banyak kasus akan meningkatkan taraf kepercayaan. Bedanya adalah, studi kasus tunggal hanya memungkinkan peneliti untuk memahami satu kasus yg unik/khas, sementara pada studi kasus ganda, peneliti dapat meneliti beberapa kasus untuk mengetahui persamaan atau perbedaan di antara kasus. Multiple case dapat digunakan ketika (1) memprediksi 
hasil serupa (direplikasi), (2) memprediksi hasil kontras tetapi dapat diprediksi. Sebagai contoh, jika peneliti ingin meneliti karyawan yang di PHK, maka peneliti melakukan penelitian pada berbagai setting organisasi, menganalisisnya pada tiap setting atau lintas setting. Desain studi kasus ganda dianggap lebih kuat dan dapat diandalkan tetapi membutuhkan waktu dan biaya yang tidak sedikit ketika dilakukan (Baxter \& Jack, 2008). Penelitian yang menggunakan desain studi kasus ganda salah satunya adalah penelitian Rahardanto \& Subandi (2012).

\section{Pengumpulan Data}

Sumber bukti yang digunakan dalam pengambilan data berasal dari berbagai sumber, Yin (2002) menyarankan peneliti menggunakan (1) dokumen, bisa berupa surat, memorandum, agenda, dokumen administrasi, artikel surat kabar, atau dokumen apapun yang erkaitan dengan penyelidikan. Triangulasi bukti melalui dokumen berfungsi untuk menguatkan bukti dari sumber lain. Dokumen juga dapat digunakan untuk membuat kesimpulan pada suatu peristiwa, mengarah pada petunjuk palsu jika peneliti tidak berpengalaman. Dokumen dapat berbentuk arsip, seperti catatan layanan, catatan organisasi, daftar nama, hasil survei. (2) Wawancara, merupakan sumber paling penting. Bentuk wawancara terbuka, yaitu partisipan berkomentar tentang peristiwa tertentu, mereka dapat mengusulkan solusi atau memberikan wawasan atas suatu peristiwa, menguatkan bukti dari sumber lain. Peneliti harus menghindari ketergantungan pada satu partisipan, dan perlu mencari data yang sama dari sumber lain untuk memverifikasi kebenarannya. Wawancara terfokus/terstuktur digunakan dalam situasi di mana partisipan diwawancarai untuk jangka waktu tertentu untuk menjawab pertanyaan yang ditentukan. (3) Observasi langsung dilakukan ketika kunjukan lapangan selama studi kasus dan lebih handal jika dilakukan lebih dari satu orang. Pengamatan partisipan dapat dilakukan untuk membuat peneliti terlibat aktif. (4) Artefak, berupa bukti fisik lain yang dikumpulkan selama pengambilan data lapangan. Sedangkan Stake (1995) menyarankan penggunaan observasi, wawancara dan telaah dokumen dalam penelitian studi kasus

\section{Analisis Data}

Analisis data dapat menggunakan analisis kualitatif, maupun kuantitatif. Kuantitatif yang dimaksud adalah angka atau nomor yang mungkin digunakan sebagai diskripsi data. Yin (2002) mendefinisikan analisis "consists of examining, categorizing, tabulating, testing, or otherwise recombining both quantitative and qualitative evidence to address the initial propotions of a study". Yin merekomendasikan dalam analisis data dengan mengkategorikan data kemudian mengatur data dengan empat cara, yaitu pencocokan pola, membangun penjelasan, menemukan logika model, dan melakukan analisis timeseries. Teknik tambahan dilakukan ketika menggunakan beberapa kasus, disebut sebagai sintesis untuk mencari pengulangan dalam kasus. Produk akhirnya adalah narasi yang menceritakan tentang kasus, yang memungkinkan pembaca sepenuhnya menjadi paham pada pada kasus yang terjadi.

\section{Validasi Data}

Para peneliti yang menggunakan studi kasus perlu menjamin validitas data melalui beberapa hal, yaitu validitas konstruk yang didapatkan melalui triangulasi berbagai sumber bukti, rantai bukti dan pengecekan data. Validitas internal didapatkan melalui penggunaan teknik analitik yang telah 
ditetapkan seperti pencocokan pola. Validitas eksternal melalui generalisasi analitik dan reliabilitas melalui protokol atau tata cara urutan melakukan studi kasus

\section{Kritik terhadap Studi Kasus}

Pendekatan studi kasus tidak lepas dari kritik. Idowu (2016) menegaskan bahwa mayoritas kritik terhadap metodologi dalam studi kasus. Kritik yang paling sering adalah ketergantungan pada kasus tunggal yang menjadikannya tidak dapat digeneralisasi. Studi sejumlah kecil kasus dalam studi kasus tidak dapat digunakan untuk membangun keandalan temuan. Penelitian studi kasus dianggap mengandung bias terhadap verifikasi, dengan kata lain studi kasus memiliki kecenderungan untuk mengkonfirmasi ide-ide yang terbentuk sebelumnya oleh peneliti. Kritik tersebut diarahkan pada statistik dan bukan generalisasi analitik yang menjadi dasar studi kasus, di mana dalam generalisasi analitik, teori yang dikembangkan sebelumnya digunakan sebagai template untuk membandingkan hasil empiris dari studi kasus. Generalisasi baik desain tunggal maupun ganda, dibuat untuk teori dan bukan populasi (Yin, 2002). Tujuan dari penelitian studi kasus adalah menetapkan parameter dan kemudian diterapkan pada semua penelitian. Validitas konstruk sangat bermasalah dalam penelitian studi kasus (Tellis, 1997), terdapat tiga solusi untuk mengatasinya, yaitu memperbanyak sumber bukti, membangun rantai bukti dan memiliki laporan rancangan studi kasus yang ditinjau oleh informan kunci.

Beberapa penelitian menggunakan judul studi kasus, contoh penelitian Budi (2006) tentang studi kasus kekerasan terhadap perempuan dalam rumah tangga di kota Yogyakarta kurang dapat memberikan gambaran 'bagaimana' kekerasan dalam rumah tangga itu terjadi, tidak menyebutkan desain studi kasus yang dimaksudkan, analisis data dilakukan secara kuantitatif. Demikian pula dengan penelitian Nurmala, Anam \& Suyono (2006) tentang studi kasus perempuan lesbian (butchy) di Yogyakarta kurang dapat memberikan kesimpulan bagaimana dinamika psikologis perempuan lesbian yang dimaksud, sumber data tunggal berasal dari wawancara, hasil penelitian belum merujuk pada parameter penelitian. Satu artikel penelitian Novita \& Siswati (2010) menggunakan terminologi desain studi kasus tunggal dalam sebuah studi eksperimen pengaruh social stories terhadap ketrampilan sosial anak. Demikian pula banyak penelitian yang menggunakan 'studi kasus' di luar atrikel yang digunakan dalam pembahasan ini, untuk menjelaskan terminologi konteks atau tempat, seperti studi kasus di PT. X, di sekolah A tetapi di dalam laporan penelitian atau publikasi artikel berisi analisis kuantitatif. Beberapa penelitian tersebut belum menggunakan studi kasus sebagai sebuah metode dalam penelitian.

\section{Penerapan Studi Kasus di Bidang Psikologi}

Meskipun banyak menggunakan studi kasus dalam penelitian, banyak psikolog enggan untuk menerima penelitian berbasis studi kasus sebagai pendekatan yang sah untuk memproduksi pengetahuan dan diseminasi hasil penelitian. Upaya untuk mempublikasikan studi kasus pada jurnal psikologi, umumnya bertemu 'kekhawatiran' tentang desain penelitian, ketergantungan pada peserta tunggal, kelompok kecil, 'tuduhan' adanya bias peneliti, dan kurangnya dukungan statistik (Hodgetts \& Stolte, 2012). Kritik terhadap studi kasus merujuk pada metodologi, yang mengganggap bahwa eksperimen dan sampel yang besar merupakan bukti dukungan dalam penelitian psikologis. Supaya pendekatan ini dapat diterima dalam psi- 
kologi, penelitian sosial menjelaskan bahwa hal itu terjadi sebagai bagian hubungan antar manusia. Psikologi memerlukan sejumlah pendekatan untuk menghadapi kompleksitas pengalaman manusia dan kehidupan sosial.

Terdapat pro kontra untuk studi kasus klinis, pada dasarnya mereka yang pro lebih merujuk adanya hal yang konkret, memiliki konteks, potensi adanya inovasi, dan menghargai klien. Sedangkan mereka yang kontra karena kelemahan metodologis terutama kualitatif yang berhubungan dengan generalisasi dan validitas internal. Flyvbjerg (2006) menyatakan bahwa terdapat lima kesalahpahaman penelitian studi kasus, yaitu bahwa pengetahuan teoritis dianggap lebih berharga daripada praktis, tidak ada generalisasi, tidak ada kontribusi pada pengembangan ilmiah, hanya berguna untuk pembuatan hipotesis dan bukan untuk pengujian hipotesis serta pengembangan teori; sering bias pada verifikasi; kesulitan menuliskan atau membuat laporan studi kasus.

Istilah studi kasus yang banyak digunakan pada bidang psikologi klinis lebih banyak merujuk pada strategi untuk menganalisis kasus klien tertentu, yang kurang merujuk pada metodologi studi kasus dalam penelitian kualitatif. Ketika mendalami kasus individual, misalnya skizofenia, lebih berpusat pada individu. Meskipun lingkungan lain juga dicari, seperti dalam definisi metodologi studi kasus, yaitu pendekatan penelitian yang berfokus pada suatu fenomena, variabel atau serangkaian variabel, hal, atau kasus yang terjadi dalam konteks waktu, tempat yang ditentukan atau dibatasi untuk mendapatkan pemahaman keseluruhan fenomena yang dikaji (Merriam, 2009; Stake, 1995, Yin, 2002). Fenomena atau kasus dapat berupa seseorang, kelompok organisasi atau peristiwa.
Penggunaan studi kasus pada bidang psikologi menarik untuk dilakukan, bukan semata-mata untuk membedah kasus tertentu. Pendekatan ini memiliki potensi untuk menangani situasi sederhana maupun kompleks. Peneliti psikologi memungkinkan untuk dapat menjawab pertanyaan 'apa' dan 'mengapa' sambil mempertimbangkan sebuah fenomena dipengaruhi oleh konteks di mana dia berada. Beberapa penelitian telah menggunakan studi kasus sebagai metodologi di bidang psikologi. Misalnya pada psikologi industri dan organisasi, Yuliawan \& Himam (2007) melakukan penelitian pada karyawan yang berpindah-pindah pekerjaan. Pada psikologi klinis, Rahardanto \& Subandi (2012) mengajukan pertanyaan penelitian "bagaimana dinamika psikologis individu yang mengalami pemilikan roh dalam konteks patologis, agama hiburan dan kuratif" dan "bagaimana rasa (inti dari perasaan, sensasi) yang dialami selama terjadi kesurupan?". Pada psikologi pendidikan, Manurung (2012) melakukan penelitian tentang school refusal pada anak sekolah dasar, Caesari \& Listiara (2013) studi kasus mengenai strategi belajar pada mahasiswa yang aktif dalam organisasi pencinta alam, demikian juga penelitian Hendriani (2016) tentang adaptasi positif pada resiliensi akademik mahasiswa doktoral. Pada psikologi sosial, Saidiyah \& Julianto (2016) melakukan penelitian problem pernikahan dan strategi penyelesaian, studi kasus pada pasangan suami istri dengan usia pernikahan di bawah sepuluh tahun.

Tujuan penelitian studi kasus adalah untuk memberikan diskripsi, menguji teori dan menghasilkan teori (Eisenhardt, 1989). Terbuka peluang menggunakan studi kasus sebagai salah satu pendekatan penelitian dan membangun teori. Eisenhardt (1989) menjelaskan tahapan penelitian menggu- 
nakan beberapa langkah, yaitu 1) Memulai penelitian dengan mendefinisikan pertanyaan penelitian, tanpa fokus penelitian, peneliti akan kewalahan menghadapi banyaknya data. Penetapan konstruk yang pada awal penelitian dapat membantu peneliti membuat desain penelitian meskipun hal ini bukan hal umum untuk dilakukan.; 2) Memilih kasus dari populasi yang spesifik; 3) Menyusun instrumen dan prosedur penelitian, di mana peneliti menggunakan metode pengambilan data dari berbagai sumber, menggunakan kombinasi data kuantitatif dan kualitatif dan menggunakan lebih dari satu investigator atau peneliti; 4) Terjun ke lapangan di mana terjadi tumpang tindih ketika pengumpulan data dan melakukan analisis termasuk dalam pembuatan catatan lapangan, pengumpulan data dilakukan secara flesibel; 5) Analisis data dengan mencari pola; 6) Membentuk hipotesis; 7) Mengkaji litetatur dengan melakukan perbandingan dengan literatur yang bertentangan maupun literatur yang sama; 8) Penutupan, di mana peneliti harus berhenti menambahkan kasus maupun data ketika kejenuhan teoritis tercapai.

\section{Merancang Studi Kasus}

Peneliti perlu melakukan rancangan penelitian dalam melaksanakan penelitian kualitatif yang menggunakan studi kasus. Beberapa langkah dan rencana praktis yang diperlukan dalam studi kasus penelitian di organisasi (Hartley, 2004), yaitu: pertama, memilih studi kasus. Peneliti perlu menentukan organisasi apa yang dicari, harus sesuai dengan kriteria yang ditentukan, apa yang menjadi ciri khas atau fenomena yang dipelajari? apakah ada kasus yang ekstrim? Apakah peneliti memiliki sumber daya jika ingin melakukan lebih dari satu kasus? Peneliti dapat menghubungi keyperson untuk menentukan populasi dari organisasi yang mungkin menarik untuk studi kasus. Kasus dapat dipilih dengan cara melakukan wawancara, misalnya pada serikat pekerja, pengusaha untuk mencari tahu tentang organisasi tertentu sebelum melakukan pendekatan langsung.

Kedua, memperoleh dan mempertahankan akses, peneliti perlu memastikan bahwa keyperson dalam organisasi memberikan akses. Bisa jadi lebih dari satu yang memiliki pengaruh untuk memutuskan apakah peneliti memperoleh ijin dalam akses data, dan berapa lama.

Ketiga, memilih kerangka teoritis awal di mana peneliti perlu memiliki fokus untuk menghindari kewalahan olah data. Namun dalam prosesnya bisa saja kerangka teoritis awal tidak sama sampai akhir. Peneliti dapat menentukan pertanyaan penelitian sederhana dengan fokus "bagaimana" dan "mengapa". Keempat, mengumpulkan data dengan sistematis, mengingat sumber data yang tersedia dari berbagai sumber. Peneliti perlu bertanya pada diri sendiri 'apakah proses yang dilakukan berasal dari informan yang cukup luas? Adakah orang lain yang memiliki pandangan berbeda? Apakah ada data yang tidak mendukung? Apakah ada catatan dokumenter yang dapat diperiksa?.

Kelima, mengelola pengumpulan data, peneliti menahan godaan untuk mengumpulkan data terus-menerus dengan pemikiran akan biaya dan pengelolaan data yang dikumpulkan. Apakah wawancara atau observasi akan menambah data dengan signifikan? Pada titik tertentu peneliti harus memutuskan berhenti mengumpulkan data. Keenam, menganalisis data, peneliti melakukan diskripsi cermat terhadap data, misalnya dengan melakukan pengelompokan dalam topik tertentu, tema utama, pertanyaan utama, menggunakan tabel untuk mencari pola. Ketujuh, menutup kasus, jika telah selesai, peneliti dapat membahas 
temuan dan rekomendasi dengan pemang$\mathrm{ku}$ kepentingan dan membuat laporan penelitian.

\section{Penutup}

Studi kasus sebagai sebuah metode memberikan kerangka atau prosedur penelitian yang harus diikuti. Yin (2002) secara rigid mengharuskan peneliti untuk pengikuti prosedur penelitian yang ditetapkan bahkan ketika peneliti mengubah desain maka peneliti perlu kembali pada prosedur awal. Yin memberikan struktur desain yang ketat pada metode studi kasus, sebaliknya Stake (1995) menyarankan desain yang fleksibel di mana peneliti dapat membuat perubahan meskipun terjadi pada proses penelitian. Tujuan penelitian studi kasus untuk memberikan diskripsi telah digunakan di bidang psikologi, baik psikologi industri dan organisasi, psikologi pendidikan, maupun psikologi sosial. Hartley (2004) menjelaskan dengan cukup rinci kapan studi kasus dapat digunakan dan memberikan panduan merancang studi kasus, meskipun penjelasannya dalam setting organisasi namun tidak menutup kemungkinan untuk digunakan pada setting yang lain. Penggunaan studi kasus untuk membangun teori belum dilakukan secara maksimal. Sehingga membuka peluang bagi peneliti di masa depan yang tertarik menggunakan pendekatan kualitatif studi kasus dapat menggunakan prosedur yang telah dijelaskan oleh Eisenhardt.

\section{Daftar Pustaka}

Baxter, P., \& Jack, S. (2008). Qualitative case study methodology: Study design and implementation for novice researchers. The Qualitative Report, 13(4), 544-559. Diakses dari http://nsuworks.nova.edu/ tqr/vol13/iss4/2
Budi, S. H. (2006). Studi kasus tentang kekerasan terhadap perempuan dalam rumah tangga di kota Yogyakarta. Humanitas, 3(2), 75-86

Caesari, Yasinta, K., \& Listiara, A. (2013). Kuliah versus organisasi: Studi kasus mengenai strategi belajar pada mahasiswa yang aktif dalam organisasi mahasiswa pecinta alam Universitas Diponegoro. Jurnal Psikologi Undip, 11(1), 2013. doi: 10.14710/jpu.12.2.164175

Cope, D. (2015). Case study research methodology in nursing research. Oncology Nursing, 42(6), 681-882. doi: 10. 1188/15.ONF.

Eisenhardt, K. M. (1989). Building theories from case study research. The Academy of Management Review, 14(4), 532-550. doi: $10.2307 / 258557$

Flyvbjerg, B. (2006). Five misunderstandings about case-study research. Qualitative Inquiry, 12(2), 219-245. doi: 10.1177/ 1077800405284363

Hartley, J. (2004). Case study research dalam Cassel, D \& Symon, G. Essential guide to qualitatice methods in organizational research (eds). London: SAGE Publications. doi: 10.4135/978144628 0119.n9.

Hendriani, W. (2017). Adaptasi positif pada resiliensi akademik mahasiswa doktoral. Humanitas, 14(2), 139-149

Hentz, P. (2017). Overview of case study research. Dalam Chesnay, M. (Eds). Qualitative designs and Methods in Nursing (pp.1-10). New York: www.springerpub.com

Hodgetts, D. J., \& Stolte, O. M. E. (2012). Case-based research in community and social pychology: Introduction to the special issue. Journal of Community $\mathcal{E}$ Applied Social Psychology, 22, 379-389. doi: 10.1002/casp.2124 
Idowu, O. M. (2016). Criticisms, constraints and constructions of case study research strategy. Asian Journal of Business and Management, 4(5), 184-188

Johanson, R. (2003). Case study methodology. International Conference "Methodologies in Housing Research" organised by the Royal Institute of Technology in cooperation with the International Association of People-Environment Studies, Stockholm, 22-24 September 2003.

Krampen, D., \& Krampen, G. (2016). Case studies in clinical psychology: Are we giving up a publication type and methodology in research on and teaching of psychopathology and psychotherapy?. International Journal of Psychological Studies; 8(3). doi: 0.5539/ ijps.v8n3p173.

Manurung, N. (2012). School refusal pada anak Sekolah Dasar. Jurnal Psikologi Undip, 11(2), 2012. doi: 10.14710/ jpu.11.1.10

Merriam, S. B. (2009). Qualitative research: A guide to design and implementation. San Francisco, CA: Jossey-Bass. doi: 10.12691/rpbs-2-1-4.

Merriam, S. B., \& Tisdel, E. J. (2015). Qualitative research: A guide to design and implementation. Fourth edition. San Fransisco: Jossey-Bass.

Nurmala, D., Anam, C., \& Suyono, H. (2006). Studi kasus perempuan lesbian (butchy) di Yogyakarta. Indonesian Psychological Journal, 3(1), 28-37
Novita., \& Siswati. (2010). Pengaruh social stories terhadap keterampilan sosial anak dengan Attention-Deficit Hyperactivity Disorder (ADHD): Studi eksperimental desain kasus tunggal di Sekolah Alam Ar-Ridho Semarang. Jurnal Psikologi Undip, 8(2), 102-116. doi: 10.14710/jpu.8.2.102-116.

Rahardanto, M., \& Subandi. (2012). From acute pain to intense elation: The psychological dynamics of five individuals who experienced spirit possession. Jurnal Psikologi, 39(1), 25-45. doi: 10.22146/jpsi.6965.

Stake, R. (1995). The art of case research. Thousand Oaks, CA: Sage Publications. doi: $10.2307 / 329758$.

Saidiyah, S., \& Julianto, V. (2016). Problem pernikahan dan strategi penyelesaiannya: Studi kasus pada pasangan suami isteri dengan usia perkawinan dibawah sepuluh tahun. Jurnal Psikologi Undip. 15(2), 124-133. doi: 10.14710/ jpu.15.2.124-133

Tellis, W. M. (1997). Introduction to case studi. The Qualitative Report, 3(2), 1-14. Diakses dari http://nsuworks.nova.edu/t $\mathrm{qr} / \mathrm{vol} 3 /$ iss $2 / 4$

Yuliawan, T. P., \& Himam, F. (2007). The grasschopper phenomenon: Studi kasus terhadap professional yang sering berpindah pekerjaan. Jurnal Psikologi, 34(1). doi: 10.22146/jpsi.7090.

Yin, R. K. (2002). Case study research: Design and methods (2rd ed.). Thousand Oaks, CA: Sage. 